DOI: $10.1515 /$ pts-2014-0033

\title{
SAIL-TYPE WIND TURBINE FOR AUTONOMOUS POWER SUPPLAY: POSSIBLE USE IN LATVIA
}

\author{
S. Sakipova ${ }^{1,2}$, A. Jakovics ${ }^{2}$ \\ ${ }^{1}$ E.A.Buketov Karaganda State University, \\ 28 Universitetskaya Str., Karaganda, 100028, KAZAKHSTAN, \\ ${ }^{2}$ Laboratory for Mathematical Modelling of Technological and Environmental \\ Processes, University of Latvia, \\ 8 Zellu Str., Riga, LV-1002, LATVIA
}

\begin{abstract}
Under the conditions of continuous increase in the energy consumption, sharply rising prices of basic energy products (gas, oil, coal), deterioration of environment, etc., it is of vital importance to develop methods and techniques for heat and power generation from renewables. The paper considers the possibility to use a sail-type wind turbine for autonomous power supply in Latvia, taking into account its climatic conditions. The authors discuss the problems of developing a turbine of the type that would operate efficiently at low winds, being primarily designed to supply power to small buildings and farms distant from centralized electricity networks. The authors consider aerodynamic characteristics of such a turbine and the dependence of the thrust moment of its pilot model on the airflow rate at different angles of attack. The pilot model with a changeable blade shape has been tested and shows a good performance.
\end{abstract}

Keywords: renewable resources, wind energy potential, sail-type wind turbine, changeable blade shape, thrust force.

\section{INTRODUCTION}

Ever rising prices of electricity, the heating and operating expenditures for maintenance of premises quicken the interest in alternative energy sources and in so-called passive houses. The main feature of such a house is that it does not need power for heating or needs only insignificant power for this purpose - average $\sim 10 \%$ of the specific energy consumed by the majority of modern buildings [1-3]. In developed European countries, specific requirements to the passive house standards are in force. As a rule, the indicator of energy efficiency for an object of the type is the heat energy loss per square metre during a year or a heating season, $100 \div 120 \mathrm{~kW} / \mathrm{m}^{2}$ on the average. Therefore, as energy-efficient is considered the building where the mentioned indicator is lower than $40 \mathrm{~kW} / \mathrm{m}^{2}$. in developed European countries this figure is even lower $\left(\sim 10 \mathrm{~kW} / \mathrm{m}^{2}[4]\right)$. At the Laboratory for Mathematical Modeling of Environmental and Technological Processes, University of Latvia (UL), research into the thermal properties of popular construction materials from local raw stuff has been conducted since 2011 in the framework of ERAF and ESF projects. In the UL 
Botanical Garden five test stands have been built for investigation of the relevant heat, air, and humidity exchange processes $[5,6]$.

A perfect passive house should possess an independent power system which would not require expenses for maintaining a comfortable temperature. For heating such a house the heat generated by its inhabitants and houshold appliances should be sufficient. If additional "active" heating is needed, alternative energy sources could be used. However, in the climatic conditions of Latvia, where the temperature in winter falls to minus $15-20^{\circ} \mathrm{C}$ with only $40-45$ sunny days a year, an additional source of energy for heating and electricity supply is necessary for normal human life. Now it is quite possible to use for these purposes advanced techniques for deriving energy from renewable sources. The most suitable alternative energy source is wind; this is confirmed by ever increasing capacity of wind turbines (WTs) in the world: in recent years its growth rate by an order of magnitude outruns that for all other types of power plants [7-10].

The wind turbine or wind power unit (WPU) is a device for converting the kinetic energy of wind flow into mechanical energy of rotation and its further conversion into electric energy. Its main difference from the conventional thermal electric and nuclear power plants (NPPs) - as well as its advantage - is the complete absence of starting raw materials and waste. In fact, the owner of an autonomous power plant becomes independent of traditional energy producers.

Wind energy is inexhaustible, available everywhere and more environmentfriendly. Inconstancy of wind does not cause any trouble when the wind share in the overall electrical power generation is insignificant. But the greater is this share, the greater is the number of reliability problems related to the electricity production. To solve problems of this kind, the intelligent management of electric wind power distribution is to be done.

It is known that all the types of energy production are irregular; with renewable energy sources it happens more often. At the same time, irregularity of wind speed is understandable, more predictable and much "safer" than, e.g., the radiation leak at a nuclear power plant's malfunction, or nitrogen and sulfur oxide emissions at heat-andpower cogeneration [2]. Coal, nuclear or hydroelectric power plants with a power of $1 \mathrm{GW}$ should have stand-by equipment for contingency or emergency cases. Conventional and nuclear power plants can stop and fail in milliseconds, while the operation of WTs can be suspended in order to protect them from the storm. It is much easier to predict weather conditions than a sudden blackout of an NPP. The more so, instability of the wind does not bring about such dangerous negative consequences for the environment as e.g. depressurization of power generating units at NPPs. Sometimes the danger of wind turbines for wildlife is mentioned, as the WT rotating blades can be a hazard to some species of living organisms. According to statistics, the blades of each installed turbine can cause the death of at least four birds per year, but this is still less than the harm from cars. The noise produced by the wind turbines might be perceived as excessive by humans and animals living nearby; but this is noticeable in the case of high-power WTs, which are usually placed far away from settlements.

Below, some aspects of modern development of wind power engineering in the world are considered, and the possible use of sail-type WTs in the conditions of Latvia is discussed. 


\section{CONDITIONS AND PROSPECTS OF WIND POWER ENGINEERING}

Nowadays, in line with the expected complete abandonment of nuclear energy proposed by the European Commission, the programme to reduce the use of traditional energy sources in the European Union (EU) is supported at the state level. The aim of EU governments is to increase the share of wind power up to $20 \%$ of the total energy consumption by 2020 . Some EU countries have already achieved this aim, and now the wind power engineering is one of the fastest growing industries in the world. According to the World Wind Energy Association (WWEA) data as of 2012, a $32 \%$ increase in the wind power production was reached in 10 years [9]. Wind occupies a highly important place among other sources of energy, and in the future will only grow in efficiency. WWEA data evidence that in 2012 the wind power made up $52 \%$ of other types of renewable sources (Fig.1).

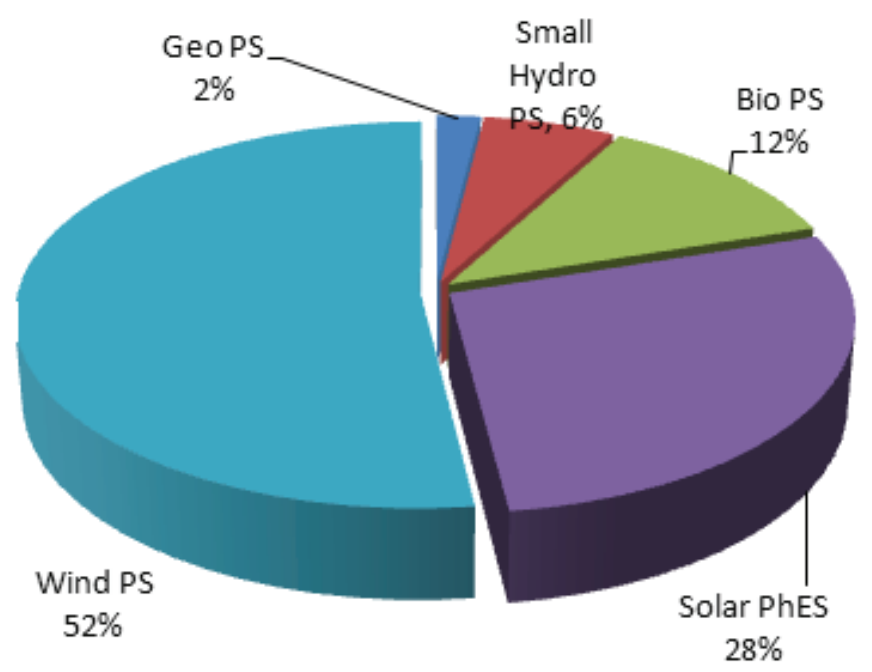

Fig. 1. The structure of the use of renewable energy sources in the world (2012)

The investments in the wind power engineering are expected to increase owing to important social and economic benefits, such as: environmental safety and reduction of emissions into the environment; reduced dependence of the state on imported oil and gas; better employment and gains in the tax revenues; the development of new technologies, etc.

In September 2012, the European Wind Energy Association (EWEA) announced that in the EU the total installed capacity of wind power plants reached $100 \mathrm{GW}$ (half of which in the previous six years). It is important that this capacity is sufficient to provide electricity to 57 million residential buildings throughout the year [9]. According to the WWEA report for the year 2013 (published in Shanghai in April 2014), the top ten most developed wind energy markets include those of China, the United States, Germany, Spain, and some others (see Fig. 2). These countries accounted for $84.77 \%$ of the total wind power capacity (318.53 MW) in 2013 [10]. From this official source it follows that in 2013 the wind energy was used for heat and electricity production $(640 \mathrm{TWh})$ in 103 countries. Some of them possessed 
particularly high percentage of wind energy use for electricity production: the Netherlands - 34\%, Spain - 21\%, Portugal - 20\%, Ireland - 16\%, Germany - 9\% (Latvia occupies the $52^{\text {nd }}$ place).

As compared with 2010, in 2012 the total generation of wind power in Latvia increased more than twice and was (68 MW) [9]. The amount of power obtained from wind in 2013 was the same as in 2012 (Fig. 3). Specialists of Latvenergo JSC claim that the use of wind energy is unprofitable: at this stage, the cost of energy obtained from renewable energy sources is considerably higher than that for energy derived from conventional ones.

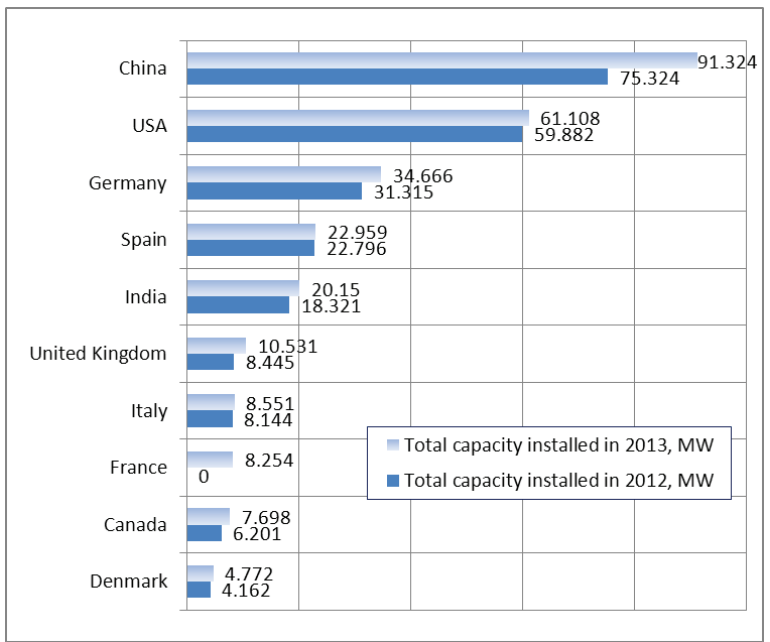

Fig. 2. Top 10 countries with maximum total capacity of wind energy

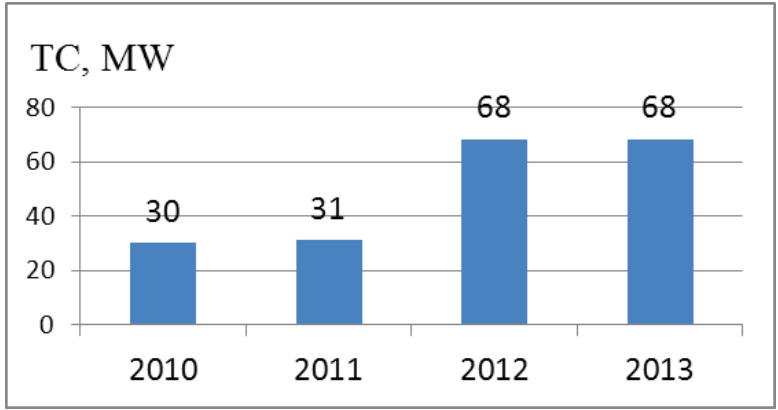

Fig. 3. Total power generated from renewable wind energy in Latvia

According to Latvenergo data, the share of wind power sector in the local power production industry is greater than 5\%. Nevertheless, in 2012 on June 15 (the International Day of Wind Energy) it was reported that the Latvian Enefit Co. sold $72 \mathrm{GW}$ of electricity produced using wind energy. This allowed reducing emissions of carbon dioxide into the atmosphere by $\sim 56$ thousand tons, which is equivalent to the total annual emissions from 28 thousand vehicles [11].

Figure 4 shows the amount of energy produced from renewable resources in Latvia, and the share of different sources in 2010 [12]; the wind power share in- 
creased in that year up to $6 \%$. Currently, the Baltic Wind Power Co. is planning to build a $100 \mathrm{MW}$ wind power plant. The production of energy using renewable sources and co-generation is a very important part of the Latvian power industry [13].

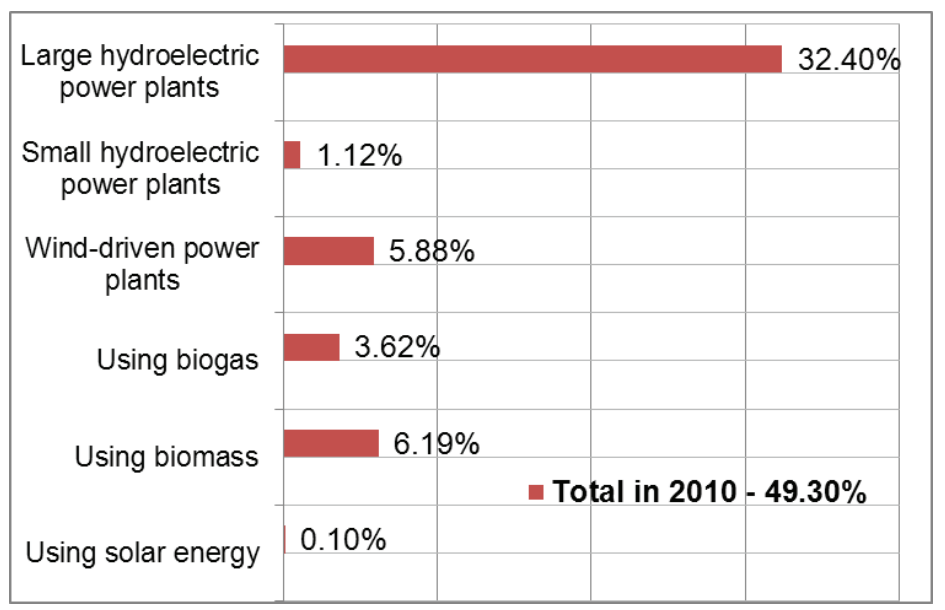

Fig. 4. Use of renewable sources in Latvia in 2010

The fact that in 2013 Latvia did not add a single watt of energy generated by wind power can be attributed to a number of objective and subjective reasons. The main reason is a general pessimistic public image of wind power use in Latvia originated from poor awareness and promotion. One of the reasons is the high cost of the equipment for wind power conversion, since the development of wind energy resources requires significant investments. To repay expenses on the construction of a WPP, the average wind speed should be $7 \mathrm{~m} / \mathrm{s}$, while in Latvia winds blow at an average speed of $\leq 5 \mathrm{~m} / \mathrm{s}$. Strong winds blow only along the coast, and there already are powerful wind farms. The governmental agencies engaged in power supply and the entrepreneurs analyze the effectiveness of the existing wind farms before investing in the wind power engineering. Information on the strength and direction of local winds as well as on other important parameters has still not been fully summarized. It is almost impossible to develop projects for wind power generation in Latvia without this information, as it is not completely clear whether there is any sense in them. Taking into account all these factors, the authors of this work discuss possible development of small WPPs under the climatic conditions of Latvia.

\section{ANALYSIS OF THE WIND POTENTIAL IN LATVIA}

In most regions of Latvia there are areas where the annual average wind speed is (3-4) $\mathrm{m} / \mathrm{s}$. In 2001-2003, within the framework of the UNDP and GEF programmes, the Danish National RISO Laboratory carried out studies of wind power resources in seven coastal regions of Latvia, with measurements of wind performed [14].

At the Sārnate settlement anemometers were installed at a height of 21.7 and $31.3 \mathrm{~m}$; the recorded values of annual average wind speed were $5.7 \mathrm{~m} / \mathrm{s}$ and $6.2 \mathrm{~m} / \mathrm{s}$, accordingly. The wind speeds recorded at the same time within the same period at the nearest weather stations in Liepaja and Pavilosta at a standard height of $10 \mathrm{~m}$ were only 3.67 and $3.05 \mathrm{~m} / \mathrm{s}$, respectively. In Fig. 5 it is seen that the areas with high 
wind speeds are found only in the coastal region of the Baltic Sea and on the coast of the Gulf of Riga [15].

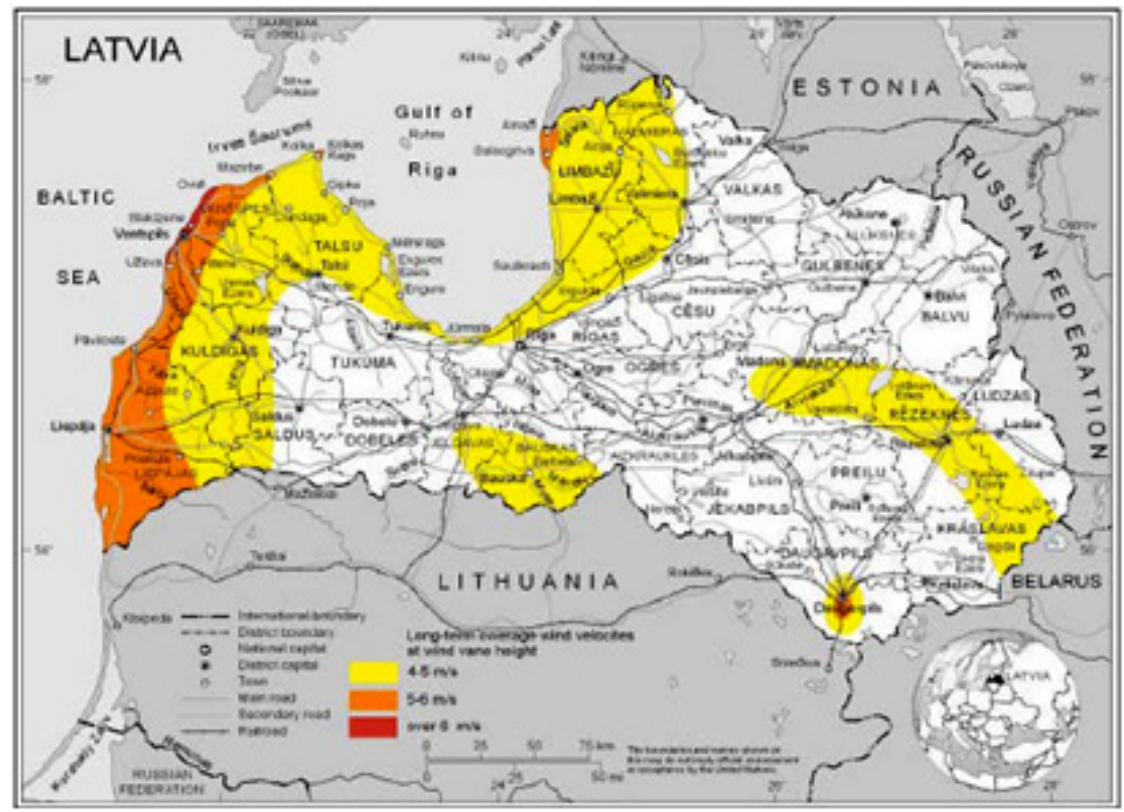

Fig. 5. The map of winds in Latvia according to the average annual speed

The width of the area with strong winds on the Baltic Sea coast is $15-20 \mathrm{~km}$, and in the region of the Gulf of Riga it is $10-15 \mathrm{~km}$. The wind speed is there up to $5.1-5.8 \mathrm{~m} / \mathrm{s}$ and greater. Within $20 \%$ of the country territory the wind speed is $4-5 \mathrm{~m} / \mathrm{s}$, and throughout the rest part it is $<4 \mathrm{~m} / \mathrm{s}$. In general, the southern, south-western and western winds dominate across the territory of Latvia. The strongest winds blow in November, December and January; the average monthly rate is $\sim 4 \mathrm{~m} / \mathrm{s}$. The weakest winds are typical of July and August, with the average monthly rate being $\sim 2.8 \mathrm{~m} / \mathrm{s}$.

In 2010-2011, the scientists of Latvia and Estonia made a collaborative basic research within the framework of GORWIND project [16]. They investigated the characteristics of winds and the ice formation in the Gulf of Riga. They also studied the sites and conditions of habitats of birds, seals and other animals, as well as analyzed climate changes. The data on the wind potential received by these specialists have been confirmed by the information obtained by regular wind speed measurements carried out by the Latvian Center for Environment, Geology and Meteorology (LCEGM) whose meteorological station is located near the Riga International Airport [17]. The on-site information is available for the pressure, temperature and humidity of air, wind speed and its direction, solar radiation intensity and other parameters throughout Latvia (see Fig. 6).

Precise values of wind speed rates (at interval of a minute) in Riga which are measured at the weather station in the BG of the University of Latvia can be received on-line. The operative information on wind speed in winter is also found in [18]. Figure 7 shows the wind shift during a day (on $31^{\text {st }}$ January, 2014 it was $1.68 \mathrm{~m} / \mathrm{s}$ in the average). The data analysis shows that in the central part of Latvia the average 
wind speed is $<3 \mathrm{~m} / \mathrm{s}$, and in Riga - even less than 1.37-2.1 m/s. As concerns wind turbines, they are usually inefficient at low winds $(<3 \mathrm{~m} / \mathrm{s})$.

Therefore, the use of commercial wind turbines of low or medium power is uneconomical, since they do not operate at such wind speeds.

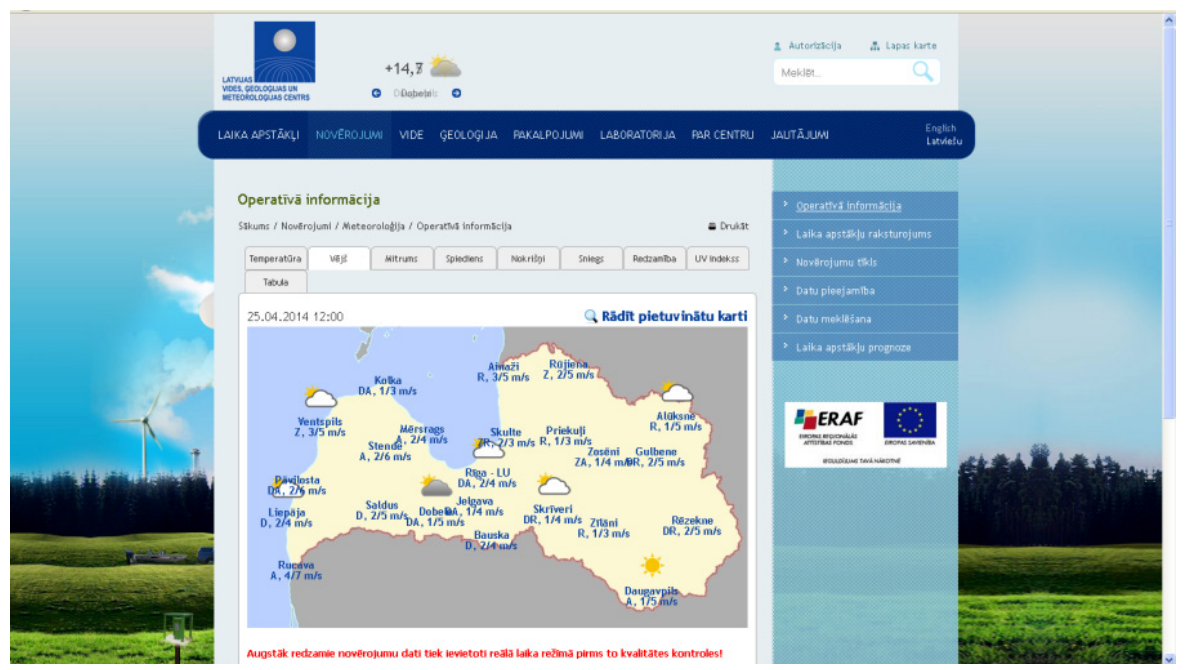

Fig.6. Pattern of operative information on the wind speed from the LCEGM meteostation

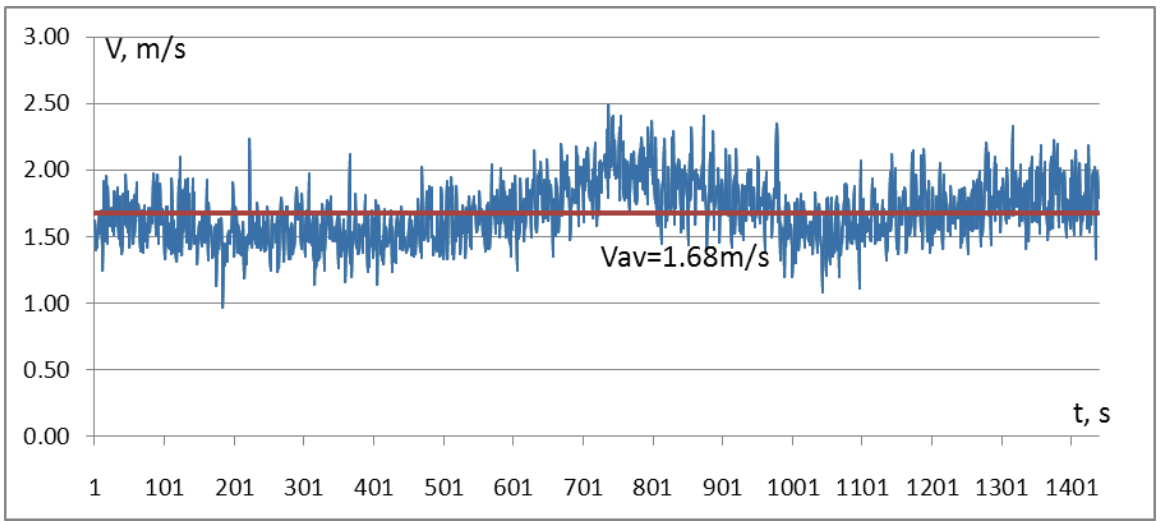

Fig. 7. The daily changes in wind speed measured at interval of a minute in Riga (31.01.2014)

However, the prospects for the use of small WTs are encouraging as applied to individual energy supply in Latvia.

\section{EVALUATION OF THE WIND TURBINE CAPACITY}

Implementation of technologies for wind power conversion is still an unsolved problem in Latvia, as in most its regions there are areas where the annual average wind speeds are about 3-4 m/s, whereas for wind turbines first of all a high annual average wind speed is required. It is therefore important to examine local wind conditions before purchasing wind turbines. 
Besides, at choosing a wind turbine for the autonomous power supply many other factors should be taken into account: the requirements of a particular customer, the quality and price of the product, etc. The main criterion for reasonable choice of equipment for power generation is the complexity of production of $1 \mathrm{kWh}$. The input complexity is in our case determined by the whole complex including the cost of WT production, transportation, installation and operation as well as of the land on which this wind turbine is to be mounted $[7,8,18]$. Choice of the WT design is reduced to finding the optimum function of many parameters and variables: $B_{o p t}=f\left(x_{i}, \ldots, x_{n}\right)$, and is to be achieved at the minimum labour expenditure [19].

The efficiency of a wind turbine could be estimated based on the known WT power dependence on the wind speed. The wind power efficiency coefficient $\xi$ can be determined by dividing the power imparted from the wind to the wind turbine $N_{g}$ by intrinsic wind power $N$ [20]. Inturn, from the formula below it follows that when the wind speed doubles, the WT output increases eight-fold:

$$
N_{g}=S \cdot \frac{\rho \cdot V^{3}}{2}
$$

where $V$ is the wind speed, $\rho$ is the density of air, $S$ is the windy area equal to the midship section of the wind wheel.

The density of air $\rho$ is a constant value; the wind speed $V$ is difficult to predict, while the $S$ value can be controlled. First, $S$ depends on the area (radius) of the wind wheel blown by the air flow and the level of filling the wind wheel - i.e. on its design. Second, $S$ depends on the wind direction: its maximum is at this direction being perpendicular to the surface of the wind wheel rotation along the axis of rotation. More precisely, at calculation of the WT power it is necessary to take into account the $\xi$ dependence on the specific speed $\chi$ of the wind turbine. This latter coefficient $(\chi)$ depends on the WT design (is determined experimentally in each particular case based on the test results). In approximate calculations we can assume that

$$
\chi=\frac{\omega \cdot R}{\bar{V}},
$$

where $\omega$ is the angular velocity of rotation of the wind wheel with radius $R$, and $\bar{V}$ is the average wind speed.

Some authors suggest various semi-empirical $\xi$ dependences on the specific speed $\chi$. For example, in [21] for a sail-type wind turbine with rectangular blades and the vertical axis of rotation the following dependence is given:

$$
\xi=0.0534 \cdot \chi \cdot\left[7.1732-6.29 \cdot \chi+0.082 \chi^{2}\right]
$$

Equating the derivative to zero we can find the value of the power efficiency coefficient: $\xi_{\max }=0.1099$ at $\chi=0.576$. These approximate calculations show that the blades of rectangular flat plates use slightly more than $10 \%$ of the wind power, with the rest spent on overcoming the air resistance due to the vortex forming at the 
blade edges, friction, etc. In [19], for determination of the wind flow rate the author proposed to take into account the friction of wind on the Earth's surface and the loss of the airflow rate due to the effect of torque moment $M_{\text {torq }}$, which is defined as a second moment of inertia of the air mass passing through the wind turbine. The most important characteristic of a WT is its aerodynamic efficiency. We propose to determine it experimentally as the ratio of thrust force $F_{y}$ to drag force $F_{x}: k=F_{y} / F_{x}$. It is shown that a multi-blade WT with optimum specific speed $Z \cong 1$ corresponds to the aerodynamic efficiency $k=(5 \div 10)$. Such quality is inherent to the flat and curved plates and sails, which also confirms the benefits of multi-blade WTs of the sail type.

According to the laws of conservation of energy and momentum, the magnitude $\xi$ of a wind turbine of any design cannot exceed $\xi_{\text {lim }} \cong 0.59$. The experimental data for small high-speed WTs at different wind speeds allow obtaining a quantitative estimate of the $\xi(D)$ dependence. Coefficient $\xi$ of a multi-blade low-speed wind turbine is practically independent of its aerodynamic efficiency and diameter $(D)$. We also investigated the influence of wind speed $\bar{V}$ on magnitude $\xi_{m}$ of a wind turbine with the optimum specific speed $Z_{\text {opt }} \cong 0.35$. It was established [20] that for multiblade WTs with $Z \cong 1$ the wind speed $\overline{\bar{V}}$ has virtually no influence on the $\xi_{m}$ magnitude. This suggests that the dependence $\xi=(Z)$ is invariant with respect to changes in the wind speed and diameter of the wind wheel within the range $D \approx(1 \div 5) \mathrm{m}$. More precisely, the wind power efficiency $\xi$ is a function of the specific speed $Z$ which is invariant with respect to changes in wind speed $\bar{V}$ and wind wheel radius $R$ provided that the geometric similarity is observed. Thus, a more accurate formula for calculating the power output of a sail-type wind turbine instead of (1) will be:

$$
N_{g}=\xi \cdot S \cdot \frac{\rho \cdot V^{3}}{2}
$$

The specific speed of a wind turbine depends on the load, varying from zero to the anemometric specific speed $Z_{\text {anem }}$ (in the case of its free rotation). It is also necessary to take into account the internal stresses in wind turbines, i.e. loads caused by aerodynamic and centrifugal forces as well as loads related to their weight. All this suggests that to obtain useful power by converting the kinetic energy of the wind (taking into account the ratio of investment and maintenance of $1 \mathrm{~m}^{2}$ of the area from which the wind power is derived), the best choice is sails and frame structures covered with cloth. Thus, a preliminary assessment of the wind turbine with optimal wind power efficiency shows that at low winds the sail-type WT is suitable. The advantage of such turbines in that they are able to generate electric energy at low wind, while blade-type wind turbines fail to operate at wind speeds $\leq 3 \mathrm{~m} / \mathrm{s}$. Sail-type wind turbines readily adjust to the direction of wind, are noiseless and vibration-free.

\section{RESULTS AND DISCUSSION}

For our tests, a model of the sail-type wind turbine was designed as a component of the autonomous wind power system for conversion of wind power into electricity (Fig. 8). The model contains six sail-type blades of triangular shape fixed on the frame rods (Fig. 8a). The blades are made of lightweight and durable cloth. 
The diameter of the sail wheel is $400 \mathrm{~mm}$. This WT model differs from the known analogues in that its triangular blades of dynamically variable surface shape with a movable end are used as load-bearing elements.

a)

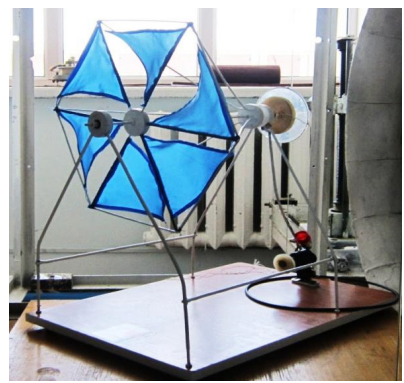

b)

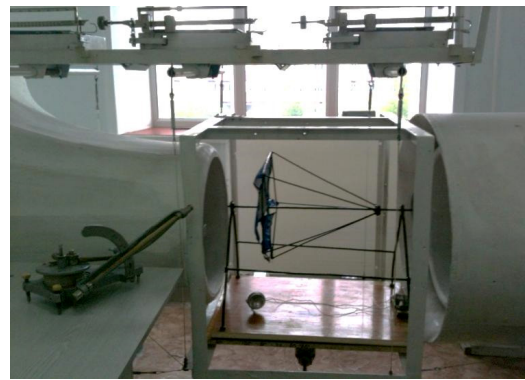

Fig. 8. The model of the sail-type wind turbine:

left - general view; right - location in the test section of a wind tunnel

Testing our model of the sail-type wind turbine was carried out in a T-I-M wind tunnel with an open test section at the Laboratory of E.A. Buketov, Karaganda State University (Kazakhstan). The methodology for measuring the aerodynamic characteristics is presented in [22]. Results of experimental investigation into the dependence of aerodynamic forces on the flow conditions are reported in [18]. The traction force $F_{t r}$ was measured using a spring dynamometer rigidly attached to the WT sheave. In the test section, the model is fixed to the cubic frame of aerodynamic balance using thin metal braces to minimize the resistance of auxiliary elements (Fig. 8b). The relevant aerodynamic characteristics were measured at different speeds and directions of the airflow. As a result of the experiments, dependences of changes in the drag force, lifting force and traction force at various flow conditions were obtained. The greatest $F_{t r}$ value in this model was in the forward direction of wind flow $\left(\alpha=0^{\circ}\right)$, since in this case the air-flown surface is the greatest.

It has been found that when the direction of airflow is reversed, the thrust moment varies in the same way as at the forward direction (see Fig.9). The differences are observed at high speeds, with increasing rate. This effect can be explained by WT operation: the wind flow exerts pressure on the triangular blades angled to the direction of this flow. The traction force converts the wind power into the rotational motion of the wind turbine.

Our experiments have shown that when the direction of wind is changed to the opposite, the rotational direction of the wind wheel axis does not change.

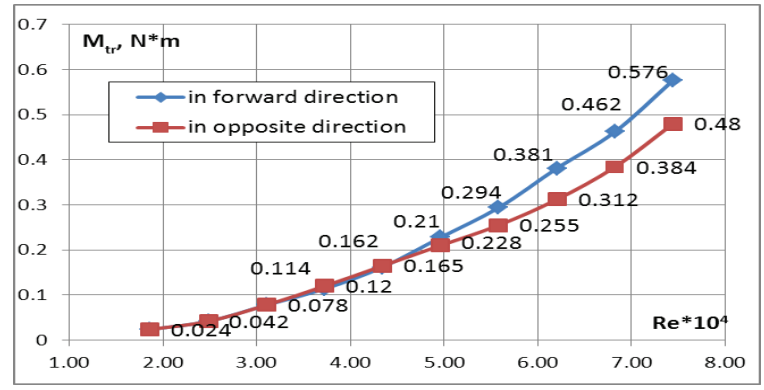

Fig. 9. Dependence of the thrust force moment on the speed of wind for its different directions 
As seen in Fig.10, blade (1) is made in the shape of a triangular "sail" with a movable end. In the case of change in the wind direction the blade "blows up "and turns over the other side of the frame, thus keeping the original rotational direction of WT axis (6). The experiments have shown that the designed model of the sail-type wind turbine with a dynamically changeable shape of the blade surface has optimum aerodynamic characteristics owing to its self-regulating abilities. The wind turbine in the air flow acts as a self-organized device capable of converting efficiently the wind energy into the energy of rotational motion.

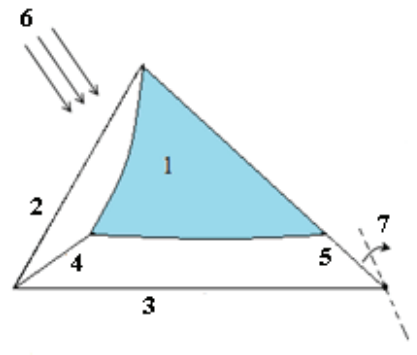

a)

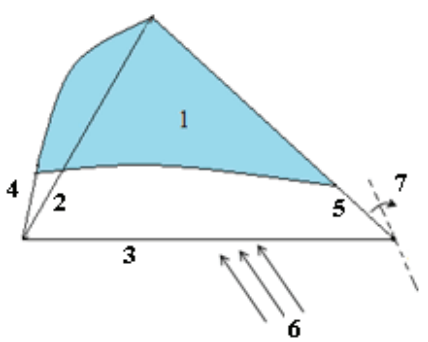

b)

Fig. 10. The scheme of wind turbine blades at the direct (a) and the opposite (b) directions of the wind: 1 - a WT blade of dynamically modifiable shape; 2, 3 - the frame of the wind wheel; 4, 5 adjustable flexible fastening (made of cord) of the expansion end of blade; 6 - direction of the wind; 7 - direction of the WT rotation

Flexibility of the design with dynamically variable surface shape of blades provides the minimum aerodynamic resistance and increases the WT efficiency. The wind turbine is operable in a wide range of changes in the wind directions. It was experimentally found that even at the reverse direction of airflow the wind turbine continues to rotate in the previous direction. Consequently, such a turbine can effectively be used if installed in the arches of houses or in a narrow space between houses where the wind blows with a greater speed and mainly in forward and reverse directions.

\section{CONCLUSIONS}

Despite the fact that wind turbines produce energy only during $25 \%$ of the total time of operation and the rest is idle time, they possess definite advantages as compared with other type turbines. Wind turbines are cost-effective (despite the inconstancy of wind) and eco-friendly, and their mechanical efficiency is ever increasing since they are constantly being improved [23,24]. It is found that the use of larger blades and smaller generators in wind turbines is more efficient at low winds. In particular, flexible sail-type blades use the incoming airflow more efficiently and produce greater aerodynamic force due to self-regulation of the shape of their surface and adjustment to different airflow rates.

The analysis of wind energy potential in Latvia made in this work shows definite prospects for development of the wind power engineering. Based on the qualitative assessment of the wind turbine capacity, we chose a sail-type wind turbine that generates energy even at wind speeds $\leq 3 \mathrm{~m} / \mathrm{s}$. The results of testing the experimental 
WT model with a dynamically modifiable blade shape in the wind tunnel under different flow conditions have proved its good performance and profitability, especially in the cases of small buildings remote from centralized power lines.

\section{ACKNOWLEGGEMENTS}

This research is done with financial support of European Social Fund; project is realized by University of Latvia, No. 2013/0027/1DP/1.1.1.2.0/13/APIA/VIAA/007.

\section{REFERENCES}

1. Bezrukih, P.P. (2010). Wind power. Directory and a methodical guide. Moscow: Energy.

2. Abdrakhmanov, R.S. \& Yakimov, F.V. (2001). The effectiveness of using wind energy sources with reduced wind speeds. Izvestiya RAN. Energy, (5), 54-57.

3. Marin,V.P. \& Sidorov, A.V. (2012). Alternative electricity is a step towards future technologies. High Tech.,13(10) Moscow: Radio Engineering, 010-019.

4. Energy Saving Technologies. www.ppu21.ru/article/303.html

5. Projects of the test stands energy efficiency monitoring. www.eem.lv/ESFindex.

6. Jakovich, A., Gendelis, S., Ozolins, A. \& Sakipova, S.E. (2014). Energy Efficiency and Sustainability of Low Energy Houses in Latvian Climate Conditions. Int. Conf." Energy, Environment, Development and Economics", 17-21 July, pp.109-114. Santorini (Greece).

7. Glickson, D. (Jan. 2014). New Test Facility to Improve Wind Turbines Renewable Energy News \& Information. http://www.renewableenergyworld.com/

8. Alternatives in Power Engineering (Nov.19, 2013). http://www.echo.msk.ru/blog/ duki21041996/

9. World Wind Energy Association Report (2012) www.wwindea.org

10. World Wind Energy Association Report (2013) www.wwindea.org

11. Free electricity market operator in Latvian Enefit (Eesti Energia) www.enefit.lv/lv/pirma-lapa

12. EBRR Renewable Development Initiative - Latvia. www.ebrdrenewables.com

13. Pavluts, D. (Sept. 3, 2012). Green energy should become profitable. http://rus.delfi.lv/ news/daily/ versions/daniel-pavlyuts-zelenaya-energiya/

14. Lizuma, L., Avotniece, Z., Rupainis, S. \& Teilans A. (2013). Assessment of the Present and Future Offshore Wind Power Potential: A Case Study in a Target Territory of the Baltic Sea near the Latvian Coast. The Scientific World Journal, ID 126428. http://www. hindawi.com/ journals/tswj/2013/126428/

15. Kenisarin, M.M., Kenisarin, K.M. (2009). Development of wind power engineering in the world and the prospects of its development in the CIS and Baltic countries. http: // www.bib.convdocs.org

16. Gulf of Riga-wind energy resource. GORWIND projects (2012). http://www.modlab.lv/ lv/gorwind_eng.php

17. Operative information of Latvian Center for Environment, Geology and Meteorology http://www.meteo.lv/meteorologijas-operativa-informacija/ ?nid=459/

18. Jakovics, A., Sakipov, S.E. et al. (2014). Development of autonomous energy supply system using a sail type wind turbine. Int. Conf." Energy, Environment, Development and Economics", 17-21 July, pp. 62 - 66. Santorini (Greece). 
19. Voitsekhovskii, B.V. (1980). Promising energy sources and their comparison. J. of Appl. Mechanics and Theor. Physics, (5), 118-125.

20. Martin, O. L. Hansen, L. (2008). Aerodynamics of Wind Turbines. London: Sterling, VA.

21. Yershina, A.K., \& Kaptagai, G.A. (2011). Theory of sailing wind turbine. Intern. Journal of Applied and Fundamental Research, (6), 128-131.

22. Sakipova, S.E., Kambarova, Zh., et al. (2013). Development of sail type wind turbine for small wind speeds. Eurasian Phys. Tech. Journal, 10(2), 20-25.

23. Gushkin, A.A. A sail wind turbine. RF Patent № 2331794. Publ. 27.03.2011.

24. Kashin, Y.A., Kashin, R.E. (2004). An autonomous wind power plant (AWPP) with a maximum level of conversion of wind energy. A mathematical model of the wind turbine. Bulletin of the Gomel State Techn. University, (3), 59-64.

\title{
BURAS TIPA VĒJA TURBĪNAS AUTONOMAI ENERGOAPGĀDEI: IZMANTOŠANAS IESPĒJAS LATVIJĀ
}

\author{
S. Sakipova, A. Jakovičs \\ K ops avilku m s
}

Darbs veltîts vienam no atjaunojamo enerǵiju veidiem - vēja enerǵijai, analizētas tās izmantošanas iespējas. Vispirms īsi raksturota vēja enerğijas izmantošana pasaulē, kā arī vērtētas izmantošanas perspektīvas no inženiertehniskā un klimatisko apstākḷu viedokḷa. Turpinājumā raksturota situācija Latvijā, t. sk., arī vēja potenciāla pieejamība dažādos reǵionos, kā arī vēja enerğijas izmantošanas efektivitāti raksturojošie lielumi. Konstatējot problēmu, rast vēja turbīnu risinājumus Latvijas apstākliem ar maziem vidējiem vēja ātrumiem, izveidots buras tipa turbīnas modelis. Šì model̦a raksturlielumu izpēte veikta vēja tunelī Karagandas universitātē, konstatējot relatīvi labus efektivitātes rādītājus tiešai un pretējai vēja plūsmai. Izmantojot mērījumu rezultātus, ierosināti sistēmas uzlabojumi, kurus plānots pētīt turpmāk. Šādas sistēmas potenciāli var rast lietojumu tur, kur nepieciešami autonomi enerǵijas avoti.

06.10 .2014 